\title{
Background and Factors of Origin of Economic Knowledge in Western Ukraine in the second half of XIX - first half of XX centuries
}

\author{
Mychajlo Holubka \\ Lviv Trade and Economic University, Ukraine \\ Department of Theoretical and Applied Economics, Researcher
}

\begin{abstract}
The scientific article is devoted to research of features of economic knowledge in Western Ukraine during the second half of the XIX - first half of the XX century, also summarizes the essence of economic knowledge and the high importance which affects the activity level of investment, entrepreneurial activity, employment, governance, and efficiency etc. The article noted that economic knowledge affects the possibility of personal fulfilment as the economically active member of society. Particular attention is given to determine the characteristics and transformation processes in the second half of the XIX - early XX century in Western Ukraine in the formation, development, and dissemination of economic knowledge among the population. Particular attention is paid to the identification of economic knowledge of business culture, which in turn includes to its structure the need to consider the public interest. Significant values of the revitalization process of the cooperative movement in the territories, forced by the Austro-Hungarian monarchy, including in western Ukraine. The analysis of the institutional framework of economic knowledge in the population allowed to mark a key role in these processes of self-organization of institutions, including the society "Prosvita" and others. Attention is paid to the peculiarities of the functioning of societies and the basic aspects of their activities. It is stated that the main purpose of the society were educational and economic spheres. The paper describes the key achievements of societies in terms of establishment and the commencement of the different organizations as associations and in order to do businesses, cooperatives, educational institutions, professional courses, publishing, the organization of specialized events and more. The results of other institutions, with the specification of their main activities for the development and dissemination of economic knowledge among the population of Western Ukraine, were studied. To form the contemporary economic knowledge to the population some economists, thinkers and their achievements on the benefits of cooperative forms of economic activity were mentioned. Features of economic knowledge in Western Ukraine in the second half of the XIX - early XX century with a focus on national values, self-organization, dissemination of professional schooling which stimulated the development of economic knowledge in Ukraine were proved.
\end{abstract}

Ключові слова: economic knowledge; economic sciences; cooperative forms; the economic culture; vocational schooling; the economy; education.

\section{Introduction}

The rationale of the research features of the study of economic knowledge in Western Ukraine during the 2nd half of the XIX - 1st half of the XX century is an important subject of research. Mentioned period of the study reveals peculiarities of formation and development of economic knowledge in areas that were controlled by Austria-Hungary, which implemented more loyal socio-cultural development policy, compared to the Russian Empire. All these processes made it possible to develop a coherent social space in order to form the Western Ukrainian
People's Republic, although it lasted a short period of time.

An important feature of intelligence and opportunities for further development of any society are the economy knowledge and handling this economic knowledge by citizens. Representatives of the professional field of study economic disciplines, in most cases, are representatives of government leaders who are active in the financial and economic situation at the macro level. The main guidelines of the national system are historical features of formation of its economic component that affects the deepening positive aspects and reduce the negative fundamentals. 
The topicality of the research is in the rationale of the efficiency trends in the spread of economic knowledge among the population of Ukraine, taking into account different time period.

The study of the problems and prospects of economic knowledge in Western Ukraine are poorly studied among Ukrainian researchers of economic specialization and in most cases is discussed among scientists of other areas.

The purpose of the article is to justify the features of economic knowledge in Western Ukraine during the second half of the XIX - early XX century along with the justification of transformational changes and trends in domestic economic knowledge system of economic development. Based on the objectives outlined we identified the main goals of the study:

- To prove the nature of economic knowledge and direction of improving their quality among population;

- Examine the environmental conditions of economic knowledge in Western Ukraine during the 2nd half of the XIX - 1st half of the XX century;

- Identify the activity features of leading public institutions (late XIX - early XX century), on the formation of economic knowledge among people by different institutions;

- To prove the most obvious signs of economic knowledge at the time of the discovery and cooperative features of economic culture, vocational schooling, extracurricular trade practices, publishers of profile specialization and more.

\section{Results}

Due to the problematic aspects of the sector, improving the quality of economic knowledge they now become a hot topic of research among all scientists. There is a shortage of professionals in the fields of financial management, accounting and auditing, insurance, Internet commerce and other economic subjects with sufficient amounts of training specialists and economists. These gaps affect very negatively because the high quality of economic knowledge has significant potential in the level of economic and business disciplines. According to L. Zahlynska and O. Lukomska, economic education revealed an increase in the level of investment resources in different sectors of the economy, not just in education; involvement of people of working age to stimulate business development and acquisition of new enterprise features in order to increase the num- ber of small and medium enterprises; the growth of self-employed persons in the sectors of the national economy; raising the competitive advantages of the Ukrainian population in the international labor markets, its confidence in the effective employment, the implementation of possibilities and wishes of each person who will contribute, and in turn, it will lead to the establishment of the progress of Ukrainian citizens [1, p. 73-74]. One of the important tasks of economic education is the consideration of possibilities of self-identity as an economically active member of Ukrainian society, which is able to consciously engage in economic life [2, p. 183]. Consequently, the structural and functional sector of economic education affects not only the formation of the knowledge but also has a positive effect on the formation of the welfare of the society.

Historical stages of economic development and education in Western Ukraine during the end of XIX - early XX centuries, according to L. and I. Potapyuk, were determined by the peculiarities of national traditions of community self-help in the exploration of life of the Ukrainian people, characterized by the first consumer societies, unions of credit direction, cooperatives movement, their fight against usury and darkness [3, p. 6]. Education due to the economic subjects is defined as an economic culture that takes into account its social basis, also taking into account the interests of others. It is worth noting that in this period only about $25 \%$ of the Galician population was able to write and read. Philistines at that time were forced to pay huge amounts of taxes and fees. Citizens did not understand why they have to pay such huge taxes and do not receive any perspective social benefits. In the second half of the XIX century, people had to adapt to the abolition of serfdom and had built up a new system of relations, which in most cases was based on such principles as mutual confrontation and minimization of coercion. The studied period should be called progressive for economic development, industrial engineering sector, the oil sector and coal mining. In this regard, the public had an opportunity to respond to the challenges of the advanced global world and developed an intelligent segment that was not always the only Ukrainian but also contained features of international origin.

It should be noted that the development of economic knowledge in Western Ukraine during the $1848-1918$ is characterized by specific features 
of social and economic transformations. First of all, the period is characterized by the development of the cooperative movement, which is an important indicator of the improvement of the economic culture of citizens. The beginning of the formation and development of cooperatives was affected by the adoption of legislation on income and economic unions in 1873. The purpose of this law was to reduce the probability of bankruptcy of small producers. This law effectively regulated the binding of cooperatives throughout the empire. In this way, the government tried to implement incentive tax revenues to the regional budget.

To enhance the institutional sector of economic knowledge of citizens the activities of such companies as "Prosvita" (1868 - creation), "Ridna Shkola" (1881 - creation) were used. These structural organizations were cultural and educational features and reinforced the goal of consolidation of Ukrainian lands across the whole territory "from the Carpathians to the Kuban", because the activities of these organizations has become an important feature of the development of the ideological standards of the population, which was necessary for an understanding of the importance of economic knowledge, ensuring the priority economic development in Western Ukraine - the consolidation and contrasting to the colonial territories. The staff of the managers of these companies included many representatives of industries such as law, art, history, writing and literature, but the leading positions were taken by teachers. These societies were the key centers of intellectual communication with the formation of their own vision of development. The greatest importance was the company "Prosvita", which in 20 years after its formation, carried out a change of the purpose from the cultural and educational spheres to education and economic sector, and started to held an active work in the economic sphere and affect the efficiency of the cooperative movement [3, with. 10]. During the 1906-1912 the "Prosvita" organized 15 cooperative courses and courses of higher education that stimulated the development of schools, including in the economic in Uhertsi Vynyavski (now - the village Green Guy, Lviv region), were founders of the Trade School in Lviv in 1911 [4].

Fig. 1 explains the key initiatives of "Prosvita":

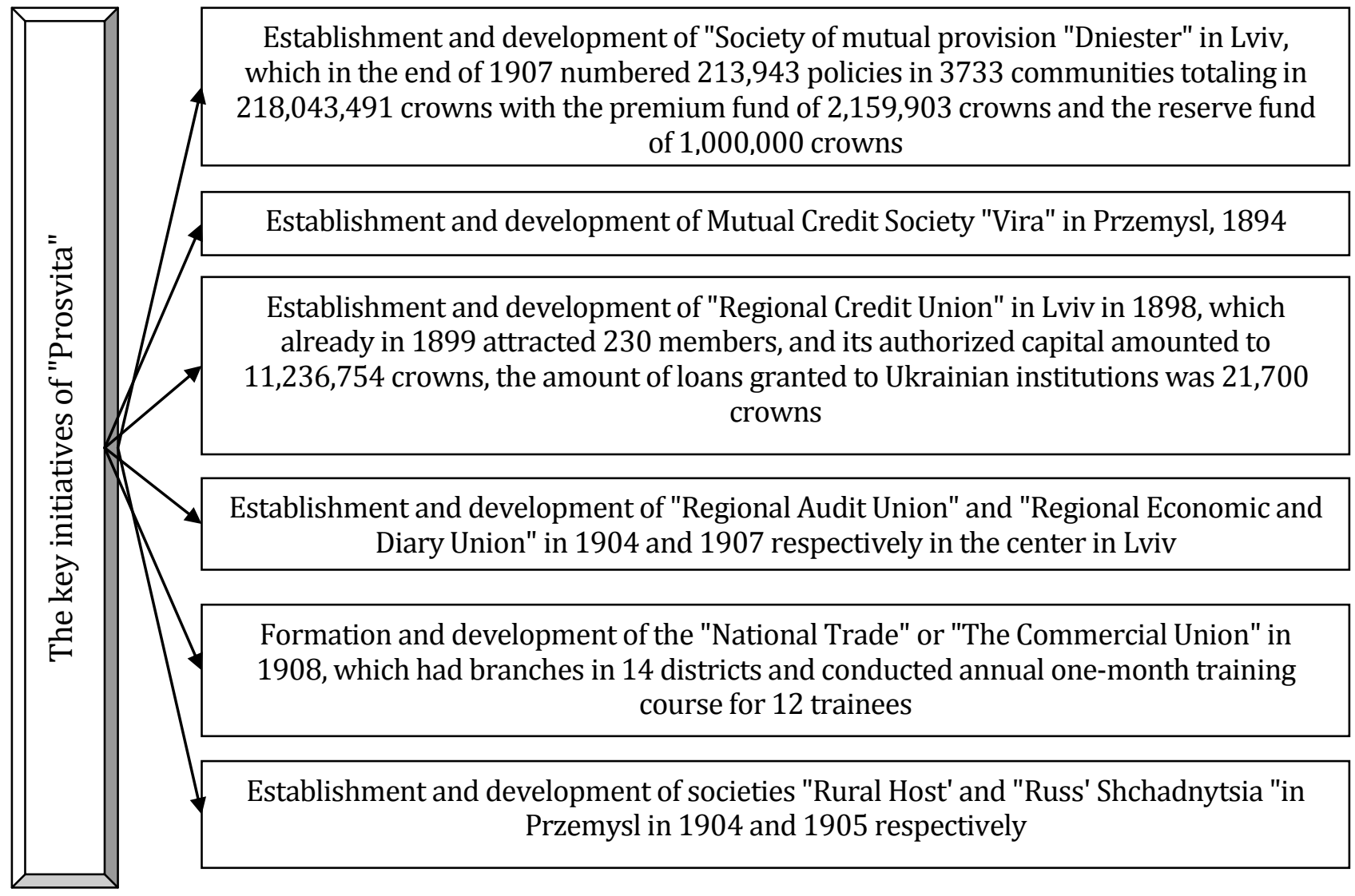

Figure 1 - The key initiatives of "Prosvita" (developed based on the data [5; 6; 7, p. 153]) 
In late 1908, as the I. Zulyak states, the structure of the society "Prosvita" credited 227 business partnerships that include the following types of organizations [7, p. 153]:

- 168 of credit direction;

- 21 of trade value;

- 10 in industrial sector;

- 10 tilling and economic organizations;
- 9 dairy companies;

- 9 other types of organizations.

Also, society "Prosvita" was peculiar with the practice of teacher-trainers who traveled to the various settlements to promote leading economic ideas of that time period. While the company held the revitalization of education and economic activity (Fig. 2).

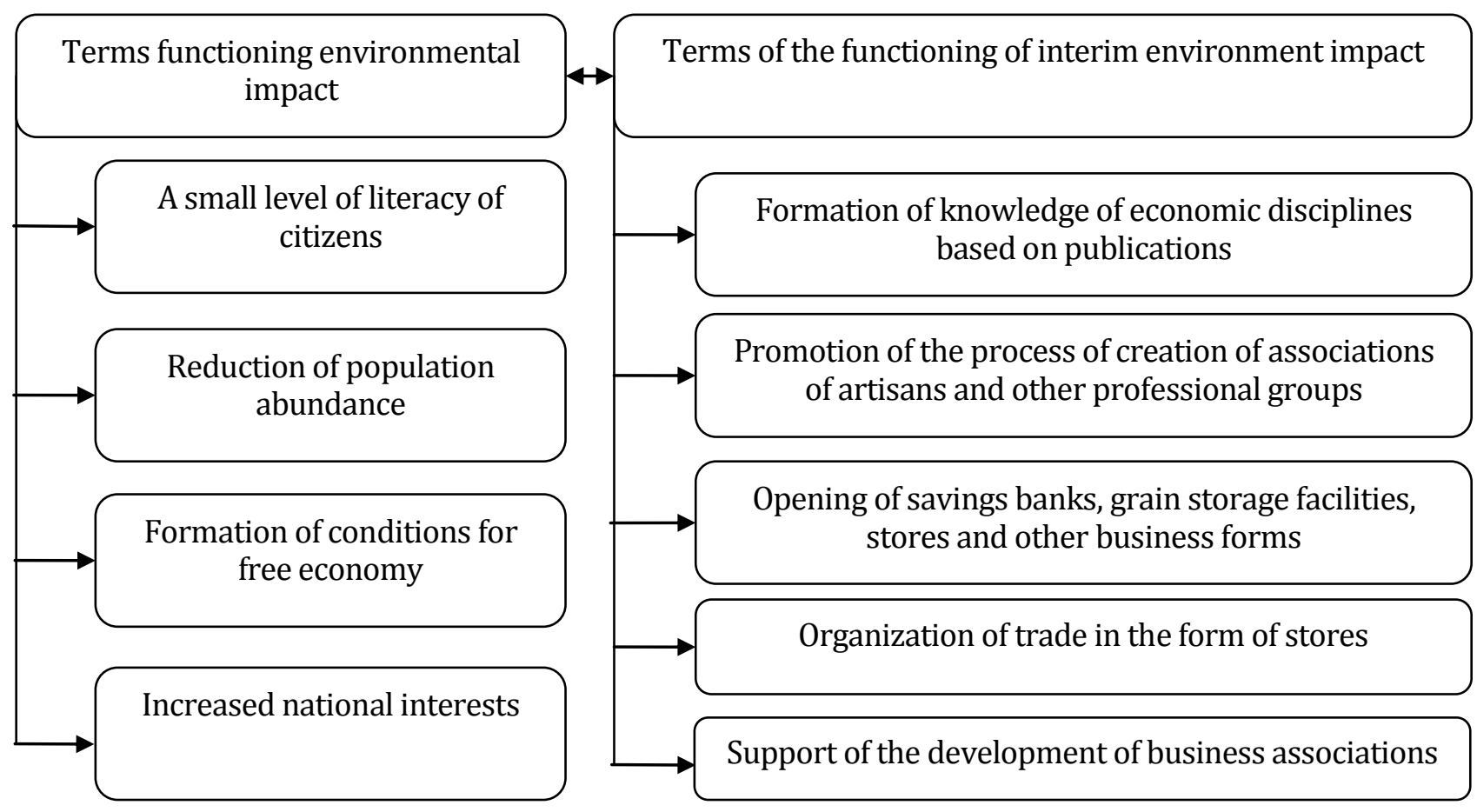

Figure 2 - Transformation of education and economic activity of the company "Prosvita" during the XIX-XX centuries (developed by author)

The great importance in the development of economic knowledge within a given time belonged to the Economic Society "Audit Union of Ukrainian Cooperatives" (AUUC), and activities in its structure such companies as: "National Trade" (the first Ukrainian Cooperative), "Rural Host", " Oil Union"," Central Union"," Central Bank "and others. Company "Rural Host" was established in 1899 and organized the educational process of selected Galicians abroad. This structure has gained significant development after 1909 and had a sufficient network of branches and over 25 thousand members. Company "Rural Host" played a significant role in shaping the economic education of people who were engaged in agriculture, thereby developing vocational education. Prominent scientists L. and I. Potapyuk believed that the most important areas of society were: formation and development of various industrial and economic unions; promotion of the implementation of agricultural knowledge among the population; organization of reading rooms, libraries, agricultural and industrial schools; implementation of conventions, courses and exhibitions; setting up of model farms, experimental stations; activation of mediation on the subject of land purchase, artificial fertilizers, tools, promotion of agricultural products, publishing the weekly "Economic magazine", the series of brochures "Library of the farmer" [3, p. 10].

Most important in the development of economic knowledge was the first Ukrainian cooperative "National trade", which was created in 1883. During the 1st year of its activity, the number of 
participants increased from 64 to 700 people. This institution's membership has helped to increase the level of practical economic knowledge. In particular, Franko in his writings of economic nature noted that cooperative in that period appeared to be the leading center of merchant world and was quite constructive and capable organization that had trade relations with a network of rural shops [8].

The development of economic life was directly and indirectly influenced by these companies. First of all, they were the centers of formation of the literacy of citizens in the development of the financial and economic thought, stimulating relationships with potentially possible inclinations. Along with this these structural units stimulated the development of the educational sector and promoted public access to economic knowledge and skills with the possibility of their use in the domestic sphere and prospects of their own business. Also, these societies have stimulated increasing importance of institutional regulation capacity of citizens to self-organization and development of progressive social challenges.

In 1909 the 1st All-Ukrainian Congress of educational and economic development to improve economic education was held; organizer of the congress was the company "Prosvita". This congress was held in Lviv and consisted of 750 participants from all over Ukraine. In particular, I. Zulyak notes that a key purpose of this meeting was to improve the economic status of Ukrainian population in rural areas, which stimulated the rise of economic life in Eastern Galicia and helped to improve the welfare of citizens [7, p. 157158]. This event points to the sufficient level of economic education and involvement of leading experts in the relevant business processes. In this regard, the Western Ukraine was characterized as an active member at the European level.

Formation and development of economic knowledge were contributed by various scientific and research printed materials. We define the specific features of research materials of the time:

- In the publication "Science", authored by Voloshyn Augustine and also other his works the benefits of cooperatives were proven, the author also made entry of cooperative legislation in Transcarpathia, which sought to protect devalued deposits of Transcarpathian cooperative unions in Budapest banks after joining the region to the Czechoslovak Republic [9];
- Korenets Denys, who made practical implementation of the stepped trade models of cooperative education and studied relevant international experience, conducted the analysis of the economic, social, cultural, demographic factors and trends of their development [10];

- Dzerovych Yulian, who was active in the priesthood cooperative "Self-help" and a publishing cooperative "Meta", also he was a longstanding member of the Inspectional Board of Tradeindustrial cooperative "Dostavka", specializing in manufacturing and supplying of religious things; Dzerovych was well aware of the importance of cooperation for fostering a sense of responsibility and the level of national consciousness, because, working in co-operation, the average person stops to think only about himself or herself and thinks about the consolidation of public opinions, and only then a person becomes a citizen [11, p. 10];

- Koberskyi Karl was a cooperative editor of the magazine "Cooperative Republic" and other publications of AUUC;

- Pavlykovskyi Yulian, who called for the creation of new cooperative centers in the county and in the region to strengthen Ukrainian element in cities and disengaging from the Polish cooperation [12, p. 54];

- Stepan Smal-Stockyi, who studied the historical aspects of economic development of Bukovina (work "Bukovynska Russ'", 1897), was an editor of the newspaper "Russ' Council" and co-editor of the newspaper "Bukovyna" and promoted the idea of the cooperative movement;

- Khraplyvyi Eugene, who was editor of the journal "Economic and Co-operative Magazine" and other publications of the later period and author of numerous works on dissemination of agricultural cooperatives;

- Eugene Olesnytskyi, a member of the editorial board of the magazine "Dilo", published his articles in the journal "Dilo", which contained the professional analysis of economic relations in the region [13].

Consequently, the general analysis of the literature of economic, political, psychological, educational areas at the time indicate that many representatives of domestic and foreign philosophers, educators, economists saw the spiritual and moral aspects of the market economy means not 
only in order to improve efficiency, but also the moral improvement of people [14].

It is also advisable to focus on the development of the professional (vocational) school system with the spread of so-called colleges (bursa) in western Ukraine. A kind of impetus in this sector was the adoption of the law on the organizations in 1872 , which contributed to the national distinctiveness; according to L. and I. Potapyuk, this regulation allowed the establishment of private schools that directly concerned vocational school system, which promoted various Ukrainian economic and cultural and educational institutions, societies that aroused the understanding of the need for creating professional schools as a means of salvation from poverty [3, p. 8]. The most widely used were the trade schools that contributed to obtaining knowledge in training and commercial expertise. Also, in this period, the school education in the commercial segment was developing. Consequently, most of the young people had the opportunity to share their achievements, skills, and knowledge in trade and economic sphere.

In late XIX century, the stimulation of the development of economic knowledge at the level of schools took place. But despite this, vocational schooling and institutionalized cooperative movement with the support of public structures undoubtedly stimulated the development of economic knowledge not only in Galicia but also in the lands of the whole Western Ukraine.

\section{Conclusions}

Thus, the development of society in Ukraine during the second half of the XIX - early XX centuries was under the influence of the Austro-Hungarian monarchy and did not have the state support of educational attainment of the population, but despite this demonstrated a very important trait of self-organization. In particular, the activities of the society "Prosvita", and other civil societies stimulated the existence of the Ukrainian intelligentsia, which was able to unite and spread national ideology. It should be noted that a characteristic feature of economic knowledge at the time was its national identity, the lack of which we see today. Exactly this experience should be used and adapted today in order to increase the value of national-patriotic spirit of modern economics and its impact on the economic development of the region.

\section{References}

1. Zahlynska, L. V., \& Lukomska, O. I. (2014). Ekonomichna osvita v konteksti investytsiinykh protsesiv $\mathrm{v}$ haluzi [The economic education in the context of investment process in the area]. Onovlennia zmistu, form ta metodiv navchannia i vykhovannia v zakladakh osvity, 9, 73-76 (in Ukrainian).

2. Tovkanets, H. V. (2014). Pedahohichnyi analiz zavdan vyshchoi ekonomichnoi osvity v Ukraini [Teaching analysis tasks of higher economic education in Ukraine]. Naukovyi visnyk Uzhhorodskoho natsionalnoho universytetu. Seriia: Pedahohika. Sotsialna robota, 31, 182-185 (in Ukrainian).

3. Potapiuk, L. M., \& Potapiuk, I. P. (2015). Stanovlennia ekonomichnoi osvity na prykladi diialnosti zakhidnoukrainskykh hromad (kinets XIX - pochatok KhKh stolittia) [The formation of economic education on the example of the western Ukrainian communities (end of XIX - beginning of XX century)]. Ekonomichnyi forum, 2, 5-12 (in Ukrainian).

4. Vseukrainske tovarystvo «Prosvita» imeni Tarasa Shevchenka. (2017, January 15.). In Wikipedia. Retrieved from https://goo.gl/3QCx5N (in Ukrainian).

5. Levytskyi, K. (1909, February). Pochatky rozvoiu nashykh ekonomichnykh instytutsii: 1890-1900 [Starts flowering of our economic institutions: 1890-1900]. In Pershyi Ukrainskyi prosvitnoekonomichnyi konhres, uladzhenyi tovarystvom "Prosvita". Lviv: n. d. (in Ukrainian).

6. N. d. (1900). Narodni Ruski tovarystva u Lvovi [People Ruthenian Society in Lviv]. In Iliustrovanyi narodnyi kalendar Tovarystva «Prosvita» na rik 1900 (vol. 23, 1-2, pp. 198-202). Lviv: n. d. (in Ukrainian).

7. Zuliak, I. (2010). Rol "Prosvity" u poshyrenni ekonomichnykh znan u skhidnii Halychyni (kinets KhIKh - pochatok KhKh st.) [The role of "Enlightenment" in the dissemination of economic knowledge in eastern Galicia (late XIX - early XX centuries).]. In Y. Isaievych (Ed.), Ukraina: 
kulturna spadshchyna, natsionalna svidomist, derzhavnist (vol. 19, pp. 151-159). Lviv: n. d. (in Ukrainian).

8. Franko, I. (1985). Narodna torhivlia [People trade]. In Zibrannia tvoriv Ivana Franka (vol. 44, 2, pp. 284-285). Kyiv: Naukova dumka (in Ukrainian).

9. Myshanych, 0. V. (2002). Zhyttia i tvorchist Avhustyna Voloshyna [The life and work of Augustine Voloshin]. Uzhhorod: Zakarpattia (in Ukrainian).

10. Hipters, Z. V. (2008). Rol pedahoha v ekonomichnii pidhotovtsi fakhivtsia na zakhidnoukrainskykh zem-liakh XIX - pershoi polovyny XX stolit. Visnyk Hlukhivskoho natsionalnoho pedahohichnoho universytetu imeni O. Dovzhenka. Seriia: Pedahohichni nauky, 12, 223-228 (in Ukrainian).

11. Pastushenko, N. (2011). Nevycherpne dzherelo pedahohichnoi mudrosti [The inexhaustible source of educational wisdom]. Pedahohichna Dumka, 1, 5-23 (in Ukrainian).

12. Potikha, 0. (2011). Osoblyvosti vzaiemyn Ukrainskoho natsionalno-demokratychnoho obiednannia z ekonomichnymy tovarystvamy Zakhidnoi Ukrainy (1930-1935) [Features relations Ukrainian National Democratic Alliance economic societies of Western Ukraine (1930-1935)]. Mandrivets, 5, 54-57 (in Ukrainian).

13. Pynda L. A. (2015). Olesnytskyi Yevhen - providnyk ukrainskoho kooperatyvnoho i khliborobskoho rukhu Halychyny druhoi polovyny XIX - poch. XX st. [Olesnytskyy Eugene conductor Ukrainian cooperative movement in Galicia and the tillage of the late XIX - early XX century]. Istoriia nauky i biohrafistyka, 4, 1-10 (in Ukrainian).

14. Hipters, Z. V. (2011). Ekonomichna osvita na zakhidnoukrainskykh zemliakh ta yii spodvyzhnyky (XIX - persha polovyna XX stolit) [Economic education at Western and its associates (XIX - early XX centuries)]. Kyiv: UBS NBU (in Ukrainian).

15. Bednarshova, T. (1997). Profesor, doktor, otets Avhustyn Voloshyn - ost. rektor UVU v Prazi [Professor, Doctor, Father Augustine Voloshin - last rector UVU Prague]. Vyzvolnyi shliakh, 5, 2745 (in Ukrainian).

16. Kachor, A. (1955). Denys Korenets: nacherk yoho zhyttia ta pratsi na tli ukrainskoho fakhovoho shkilnytstva i silsko-hospodarskoi kooperatsii v Zakhidnii Ukraini [Denis Korenets: sketch of his life and work at Ukrainian professional background and schooling of agricultural cooperatives in Western Ukraine]. Winnipeg: Vydannia "Kooperatyvnoi hromady" (in Ukrainian).

17. Lentsyk, V. (1994). Otets kryloshanyn Yuliian Dzerovych: Ostannii holova "Prosvity" [Father Julian kryloshanyn Dzerovych: Last head "Enlightenment"]. Patriar-khat, 9 (in Ukrainian).

18. Koberskyi, K. (1935). Vilne spilchanstvo (kooperatsiia) - shliakh do pidnesennia narodu [Free spilchanstvo (cooperation) - the path to ascension people]. Lviv: Samoosvita (in Ukrainian).

19. Pavlykovskyi, Yu. (1934). Pryroda, meta i svitohliad ukrainskoho kooperatyvnoho rukhu. In Kooperatyvna respublika (vol. 2, pp. 48-56). Lviv: RSUK (in Ukrainian).

20. Danylenko, V. M., \& Dobrzhanskyi, O. V. (1996). Akademik Stepan Smal-Stotskyi: Zhyttia i diialnist (1859-1938) [Academician Stepan Smal-Stocki. The life and work (1859-1938)]. Kyiv: Chernivtsi (in Ukrainian).

21. Barna, V., Havlich, I., Holovyn, B., \& Pyndus, B. (2008). Khraplyvyi Yevhen Vasylovych [Eugene V. Khraplyva]. In H. Yavorskyi (Ed.), Ternopilskyi entsyklopedychnyi slovnyk (vol. 3, pp. 562-563). Ternopil: Zbruch (in Ukrainian).

22. Chornovol, I. P. (2010). Olesnytskyi Yevhen [Eugene Olesnytskyy]. In V. A. Smolii (Ed.), Entsyklopediia istorii Ukrainy (vol. 7, pp. 581). Kyiv: Nauk. dumka (in Ukrainian).

(C) M. Holubka 